"Mircea cel Batran" Naval Academy Scientific Bulletin, Volume XIX - 2016 - Issue 1

Published by "Mircea cel Batran" Naval Academy Press, Constanta, Romania /I The journal is indexed in:

PROQUEST / DOAJ / DRJI / JOURNAL INDEX / I2OR / SCIENCE LIBRARY INDEX / Google Scholar / Crossref /

Academic Keys / ROAD Open Access / OAJI / Academic Resources / Scientific Indexing Services / SCIPIO

\title{
LEVEL OF AWARENESS OF REPUBLIC BULGARIA'S POPULATION FOR TREATMENT OF ISCHEMIC STROKE VIA THROMBOLYSIS
}

\author{
Greta KOLEVA ${ }^{1}$ \\ Irinka HRISTOVA ${ }^{2}$ \\ Despina GEORGIEVA ${ }^{3}$ \\ Daniela DRAGANOVA 4 \\ Ivanichka SERBEZOVA ${ }^{5}$ \\ ${ }^{1}$ Assist, Ruse, Riga str. 38, University of Ruse, Pedagogy Department \\ ${ }^{2}$ Assist, Ruse, Riga str. 38, University of Ruse, Pedagogy Department \\ ${ }^{3}$ Assist Prof, Ruse, Riga str. 38, University of Ruse, Pedagogy Department \\ ${ }^{4}$ Assist - Ruse, Riga str. 38, University of Ruse, Pedagogy Department \\ ${ }^{5}$ Professor, PhD, Ruse, Riga str. 38, University of Ruse, Pedagogy Department
}

\begin{abstract}
The stroke is a socially significant disease that is characterized with high levels of morbidity and mortality, causing severe disability worldwide. It is the second most significant cause of death among the people in the western world, falling back only to the heart diseases and preceding the cancer, as it causes $10 \%$ of the mortal cases in the world. Since 2009 the Bulgarian association of neurosonology and cerebral hemodynamics(BANCH) organizes different initiatives of training doctors to conduct a thrombolytic treatment to acute ischemic stroke(AIS). The intravenous thrombolysis has not been established as a leading differential treatment of AIS in Bulgaria, and the thrombolytic therapy is still not well developed in Bulgaria.

The support of national and local institutions is crucial for insuring and guarantee for a proper stroke treatment. Efforts are necessary for adequate financing of the health facilities, as well as professional preparation of the human resource, and training the population via creating an integrated national strategy for its application and control, which can underlie as a state politics in healthcare at optimal usage of publicprivate partnership.
\end{abstract}

Keywords: ischemic stroke, thrombolysis, Actilyse ${ }^{\circledR}$, stroke unit

Introduction: The stroke is an acute disturbance of the cerebral blood circulation, as a result of which, the cerebral functions are impaired to a different degree of damage. The definition of stroke, offered by the World health organization(WHO) in 1970 [19],is "a neurological deficiency with a cerebrovascular origin, running for over 24 hours, or interrupted due to death within those 24 hours". This definition shows the reversibility of the tissue damage, as the 24-hour frame is provisionally selected. It is introduced to distinguish the stroke from a TIA, which runs with very similar symptoms, but fades within 24 hours [16]. With the opportunity for an early therapy, which reduces the stroke's acuteness, many prefer to use the term cerebral attack and an acute ischemic cerebrovascular syndrome(similar to heart attack and acute coronary syndrome) [19].

The stroke comprises of two groups: ischemic and haemorrhagic [15]. The ischemic stroke is the one which is caused by a disturbance of the blood supply, whereas the haemorrhagic ones are a result of a broken blood vessel, or abnormal vessel structure. About $87 \%$ of the strokes are caused by ischemia. Some heamorrhagic strokes are developed in ischemic areas("a haemorrhagic transformation"). It is unknown how much

DOI: 10.21279/1454-864X-16-I1-072

(c) 2015. This work is licensed under the Creative Commons Attribution-Noncommercial-Share Alike 4.0 License. haemorrhagic strokes start at the beginning as ischemic ones [16]. Due to ischemic stroke, the blood supply to some part of the brain is limited, which results in disfunction or a permanent damage of this part of the brain.

There are four known reasons for this to happen:

1. Thrombosis (a local clot blockage of a blood vessel);

2. Embolism (a clot blockage formed somewhere on the body) [16]

3 . Systemic hypoperfusion (an overall reduction of the blood flow, for example in shock) [24];

4. Thrombosis of cerebral venous sinuses (vessels carrying the blood from the brain to the jugular vein) [25].

Strokes without any obvious explanation and of unknown descent are considered cryptogenic. Such are about $30-40 \%$ of all ischemic strokes $[16,18]$. But, it will soon probably become the main cause of death in the world [20]. The risk of stroke increases after the age of 30 , and its etiology changes as age progresses [17]. Advanced age is one of the most significant risk factors for a stroke to arise. $95 \%$ of the cases occur in people over 45 years old, and $2 / 3$ occur in those over 65 years old $[17,23]$. The risk for a patient to die due to acquired stroke increases as 


\begin{abstract}
"Mircea cel Batran" Naval Academy Scientific Bulletin, Volume XIX - 2016 - Issue 1
Published by "Mircea cel Batran" Naval Academy Press, Constanta, Romania /I The journal is indexed in: PROQUEST / DOAJ / DRJI / JOURNAL INDEX / I2OR / SCIENCE LIBRARY INDEX / Google Scholar / Crossref /

Academic Keys / ROAD Open Access / OAJI / Academic Resources / Scientific Indexing Services / SCIPIO
\end{abstract}

well. Still, it is possible for a stroke to occur at any age, even during childhood. The main risk factors for the stroke are the family history, as well as lifestyle. Contributive factors are hypertension, atherosclerosis, atrial fibrillation, a myocardial infarction in the past, diabetes, hyperlipidaemia,alcohol and drug abuse, etc. Among the people who went through a stroke for the first time, the higher levels of von Vilebrand factor stand out (it's a plasma protein having to do with coagulation) [14].

A past stroke is a highly great risk factor for acquiring a new one. A combined effect of several of the aforementioned risk factors, increases the risk of stroke significantly. According to the World health organization(WHO), 15 million people get ill of stroke annually around the world, 5 million of them die and 5 million remain permanently disabled. The number of stroke-ill people in Europe is expected to increase by $30 \%$ between 2000-2025 [27]. The mortality in Central and Eastern Europe is higher in comparison to that of North, South and Western Europe. 57\% of the expenses for cardiovascular diseases in the EU go for healthcare, $21 \%$ are due to loss of labour efficiency, and $22 \%$ go for care to survivors [12]. In late 2008 Bulgaria has the highest rate of mortality (14.5 to 1000 people), and is in the top places in mortality by strokes - every fifth or sixth man dies from stroke in the country, and every fourth or fifth woman, whereas in Europe- every tenth man and seventh woman [12, 28]. Moreover the sick rate and mortality from strokes is much higher among those who live in the villages [21]. The disability for those who had survived a stroke extends to $50-75 \%$.

According to the National Centre for public health and analysis, 26654 people in our country got a stroke for the first six months of 2014, 25600 of which have been hospitalized, 1054 of them have refused hospitalization and 2904 respectively of all have died, and 932 of the unhospitalized as well. 23780 patients suffer from an ischemic stroke(IS). The gender distribution is shown on Table 1.

Table 1. Number of patients by age that got IS for the first six months of 2014.

\begin{tabular}{|c|c|c|}
\hline Men & Age & Women \\
\hline 25 & under 35 years & 23 \\
\hline 1014 & from 35 to 55 years & 713 \\
\hline 10196 & over 55 years & 11809 \\
\hline
\end{tabular}

The number of Bulgarians who got a stroke in adulthood age(under 55 years), is 1875; men prevail, their mortality rate is greater. 110 patients have undergone fibrinolysis.

The differential thrombolytic treatment of AIS in Bulgaria with applying a recombinant tissue plasminogen activator(rt-PA) Actilyse $\AA$ is introduced in 2005- the first thrombolysis is made in Plovdiv [1]. Treatment with thrombolysis in Europe and the USA is applied since 2002 until now.

In Europe and the US thrombolysis is administered since 2002. Staykov quoting other sources, states as a key objective of both - the intravenous and intra-arterial thrombolysis restoration of blood flow through arteries with obturation and prevent irreversible disturbance in the area of so-called penumbra: restoring circulation and normalization of metabolism in neighboring infarct functionally impaired tissue [4] by "melting" the resultant clot. Penumbra - from the Latin "Paene" (almost) and "umbra" (shadow) or ischemic penumbra. This area can be restored by an early intervention to improve blood circulation.

By the end of 2009 in Bulgaria were made about 150 intravenous thrombolysis and several intraarterial, which is significantly below the expected minimum of $1 \%$ and varies from $0.04 \%$ (2006) to $0.1 \%$ per year (2009) [1]. Treatment is regulated by the clinical pathway №2 NHIF and is conducted in a neurology clinic / ward with intensive care unit with the possibility of respiratory support if needed, or in SICU according to current medical standard "Neurology" [11].

By 2011, in Bulgaria intravenous administration of recombinant tissue plasminogen activator (rtPA Alteplase, Actilise) applies only to the first three hours of the occurrence of ischemic stroke in persons 18 to 75 years of age (for Europe 80 years ). Although the study ECASS III (European Cooperative Acute Stroke Study III) showed good safety and efficacy of the application of rt-PA between 3-4.5 hours of the onset of symptoms [22]. This time limit may be raised to 4.5-6 hours using intra-arterial thrombolysis and $/$ or endovascular recanalization (mechanical thrombus extraction or stenting).

In other studies the authors compared the effects after stroke, and the risk of bleeding in patients treated with rt-PA to the third hour, with those in patients with intravenous thrombolysis administered between three and six hours. The conclusion is that for the certain group of patients the therapeutic window may be extended up to six hours of early vascular accident.

Similar results were obtained from a number of studies - clinically randomized and placebocontrolled, multi-centered clinical studies indicate 


\begin{abstract}
"Mircea cel Batran" Naval Academy Scientific Bulletin, Volume XIX - 2016 - Issue 1
Published by "Mircea cel Batran" Naval Academy Press, Constanta, Romania // The journal is indexed in: PROQUEST / DOAJ / DRJI / JOURNAL INDEX / I2OR / SCIENCE LIBRARY INDEX / Google Scholar / Crossref /

Academic Keys / ROAD Open Access / OAJI / Academic Resources / Scientific Indexing Services / SCIPIO
\end{abstract}

that administration of intravenous thrombolysis after the third hour, is associated with a lower incidence of intracerebral bleeding and a high percentage of recovery [8]. Experts in the field believe that there is sufficient evidence that application of Actilyse between 0 and 4.5 hours, after the onset of symptoms of acute ischemic stroke can be considered economically viable therapy, as this reduces the likelihood of disability, death or dependency on the care of others .

In November 2011 the European Medicines Agency (EMA) has approved changes in the indications of Actilyse via prolonging the application of this drug from three to 4.5 hours, after the onset of clinical symptoms in patients with acute ischemic stroke. Permit outside the three-hour time period, is based on the results of the European study ECASS 3, which is defined as a milestone in the venous thrombolysis with rt-PA. ECASS 3 was a randomized, double-blind, placebo-controlled study, which for the first time demonstrated that thrombolysis with Alteplase can increase favorable outcome with minimal or no disability after an acute ischemic stroke, when treatment is started in time window of 3 to 4.5 hours after symptom onset [13].

In Bulgaria extending the time window for administration of Alteplase to 4.5 hours was approved under a national procedure since April 2011 [9].

There are a number of contraindications, making procedures inapplicable in a relatively large number of patients with ischemic stroke, reached in a timely manner to the health facility: NIHSS neurological assessment by over 22 points, intracranial hemorrhage, increased bleeding hazard (in systolic blood pressure over 185 and diastolic $110 \mathrm{mmHg}$; a history of intracranial hemorrhage, patients anticoagulated with INR $>$ I = 1.5 , prothrombin time under $60 \%$, taking heparin and extended aPT, platelets below 100,000, brain injury in the past, or ischemic stroke over the last three months, intracranial neoplasia, AB malformation, aneurysms, hemorrhagic retinopathy / eg diabetic / severe uncontrolled hypertension, varicosis of esophagus documented gastric ulcer during the last 3 months; severe neoplastic liver disease / cirrhosis, hepatitis / or GI bleeding, or bleeding from the urinary tract during the last 21 days, arterial puncture in the last seven days; severe CNS trauma in the last three months, major surgery or serious injury in the last 14 days); blood glucose below $2.5 \mathrm{mmol} \mathrm{/} \mathrm{L;}$ seizures; myocardial infarction in the past three months, endocarditis, pericarditis, acute pancreatitis [10].
Among other reasons that determine the limited use of intravenous thrombolysis in cases of acute ischemic stroke (AIS) in Bulgaria may include: lack of Specialized units (stroke units) and trained multidisciplinary teams for its implementation; a limited number of hospitals eligible for equipment and human resources, that do not cover the entire territory of the country; the absence of a good relations between the teams of the EMS and the hospital units performing the procedure; lack of sufficient information to the public, outpatient and emergency assistance for this therapy; lack of a national registry of diseased with AIS, and a national program for the prevention of strokes. There are financial constraints and organizational problems [2].

From Andonova's and others' research for the period 2007-2009 in "St.. Marina " University hospital - Varna, it is clear that the hospitalized patients with ischemic stroke (IS) are 2935, but only 20 of them have been conducted with a thrombolytic therapy. After analyzing the technological time to implement all procedures and tests covered by the Protocol, in 97 patients is found that time ranging from 1.46 to 2.23 hours. The low frequency of thrombolysis in patients with IS is explained by the belated hospitalization and delayed lab results - after the 3rd hour of stroke onset. It is also because of poor collaboration between teams of EMS on the one hand, and the teams of a ER and the multidisciplinary team on the other hand.

The absence of a national registry of patients undergone thrombolytic therapy, takes the opportunity to analyze nationwide effect of the therapy on neurological deficit, estimated to NIHSS- scale [6]. Prof. Nedeltchev head of neurology clinic in Triemli Hospital in Zurich, shared the measures taken in Switzerland in 2010 in connection with the early recognition of the symptoms of AIS. Repeatedly in prime time television broadcast video information, is explained what could be the symptoms, and when they are recognized, that an important contact with person from the emergency servises should be done, in order to identify and confirm potential patient with stroke. The 112 operator can ask a few questions in high sensitivity in order within the time window, the patient to be transfered in a specialized center. Several specialized university hospitals in Switzerland thrombolyze $20-25 \%$ of patients with ischemic stroke. These centers admit patients especially for trombolytic procedures. Teams working in there are specially selected, and work on all known methods for thrombolysis, namely intravenous, intra-arterial thrombolysis and combined [7]. 
"Mircea cel Batran" Naval Academy Scientific Bulletin, Volume XIX - 2016 - Issue 1

Published by "Mircea cel Batran" Naval Academy Press, Constanta, Romania /I The journal is indexed in: PROQUEST / DOAJ / DRJI / JOURNAL INDEX / I2OR / SCIENCE LIBRARY INDEX / Google Scholar / Crossref /

Academic Keys / ROAD Open Access / OAJI / Academic Resources / Scientific Indexing Services / SCIPIO

In order to determine the awareness of the population about the disease Ischemic stroke, its signs and ways of treatment was conducted survey. For the purpose of the study have been designed questionnaire consisting of seven questions from a closed and one from open type. 322 adults from the town of Rousse - men and women of 18-85 years with different social status and profession had been questioned. The research period is from $1^{\text {st }}$ to $15^{\text {th }}$ May 2015.

Statistical data processing is carried out with the program SPSS 16,0. The results show low levels of awareness about the nature of Ischemic stroke, the reasons for its occurrence and opportunities for therapy.

The survey results are presented in tabular form.

Table 2. Awareness of Ischemic Stroke

\begin{tabular}{|l|l|l|}
\hline $\begin{array}{l}\text { Do you know } \\
\text { what Ischemic } \\
\text { stroke is? }\end{array}$ & $\begin{array}{l}\text { Number of } \\
\text { people } \\
\text { answered }\end{array}$ & $\begin{array}{l}\text { Number } \\
\text { people } \\
\text { answered as \% }\end{array}$ \\
\hline Yes & 158 & $49,1 \%$ \\
\hline No & 136 & $42,2 \%$ \\
\hline I have no idea & 28 & $8,7 \%$ \\
\hline
\end{tabular}

Only $49.1 \%$ of respondents know the signs of IS, which logically leads to the result shown in Table 3.

Table 3. Awareness of the signs of IS

\begin{tabular}{|l|l|l|}
\hline $\begin{array}{l}\text { Do you } \\
\text { know the } \\
\text { signs of the } \\
\text { illness? }\end{array}$ & $\begin{array}{l}\text { Number of } \\
\text { people } \\
\text { answered }\end{array}$ & $\begin{array}{l}\text { Numbeof } \\
\text { people } \\
\text { answered as } \\
\%\end{array}$ \\
\hline Yes & 136 & $42,2 \%$ \\
\hline No & 182 & $56,5 \%$ \\
\hline No reply & 4 & $1,2 \%$ \\
\hline
\end{tabular}

When asked to point out some signs of stroke occurring, 230 / 71.4\% / patients did not reply, and the remaining $28.6 \%$, gave some of the following answers: loss of consciousness, paralysis, loss of speech, eye haemorrhage, dizziness, inadequacy, rigidity, paralysis of the body, high blood pressure, brain fatigue, numbness of limbs, numbness of left arm combined with pain in the right leg, confusion, rambling speech, spontaneous release of urine and feces, when there is no blood clotting in the head, tongue twisting and others.
Table 4. Origin of information about the disease.

\begin{tabular}{|l|l|l|}
\hline $\begin{array}{l}\text { Where do you get } \\
\text { information about } \\
\text { the disease? }\end{array}$ & $\begin{array}{l}\text { Number of } \\
\text { people } \\
\text { answered }\end{array}$ & $\begin{array}{l}\text { Number of } \\
\text { people } \\
\text { answered as } \\
\%\end{array}$ \\
\hline From GP & 202 & $62,7 \%$ \\
\hline $\begin{array}{l}\text { Healthcare } \\
\text { workers }\end{array}$ & 58 & $17,4 \%$ \\
\hline From internet & 46 & $14,3 \%$ \\
\hline $\begin{array}{l}\text { From friends and } \\
\text { relatives }\end{array}$ & 4 & $1,2 \%$ \\
\hline From mass media & 2 & $0,6 \%$ \\
\hline No comment & 12 & $3,7 \%$ \\
\hline
\end{tabular}

The main source of information, as shown in Table 4 is the GP. The conclusions that can be drawn is that the information on the IS is insufficient and unclear to people.

The results presented in Table 5 confirm the importance of the GP for responding to respondents' expectations to obtain information about the disease.

Table 5. Expected information

\begin{tabular}{|l|l|l|}
\hline $\begin{array}{l}\text { Whom l } \\
\text { where from } \\
\text { do you } \\
\text { expect to } \\
\text { receive } \\
\text { information } \\
\text { about the } \\
\text { disease? }\end{array}$ & $\begin{array}{l}\text { Number } \\
\text { people } \\
\text { answered }\end{array}$ & $\begin{array}{l}\text { Number } \\
\text { people } \\
\text { answered as \% }\end{array}$ \\
\hline $\begin{array}{l}\text { Visiting the } \\
\text { GP }\end{array}$ & 202 & $62,7 \%$ \\
\hline $\begin{array}{l}\text { Information } \\
\text { leaflets m mass }\end{array}$ & 56 & $18,1 \%$ \\
\hline $\begin{array}{l}\text { From } \\
\text { media }\end{array}$ & 64 & $19,2 \%$ \\
\hline
\end{tabular}

Table 6. Expected aid

\begin{tabular}{|l|l|l|}
\hline $\begin{array}{l}\text { When first signs of } \\
\text { IS start to manifest, } \\
\text { where will you seek } \\
\text { help from? }\end{array}$ & $\begin{array}{l}\text { Number of } \\
\text { people } \\
\text { answered }\end{array}$ & $\begin{array}{l}\text { Number of } \\
\text { people } \\
\text { answered as } \\
\%\end{array}$ \\
\hline GP & 62 & $19,3 \%$ \\
\hline Number 112 & 240 & $74,5 \%$ \\
\hline Family and relatives & 14 & $4,3 \%$ \\
\hline $\begin{array}{l}\text { I will wait them to } \\
\text { go away }\end{array}$ & 6 & $1,9 \%$ \\
\hline
\end{tabular}

Most of the respondents $74.5 \%$, know that at the first sign of the disease is necessary to seek urgent help.

$20 \%$ of respondents believe that they know modern methods of treatment of IS, and $80 \%$ did 
"Mircea cel Batran" Naval Academy Scientific Bulletin, Volume XIX - 2016 - Issue 1

Published by "Mircea cel Batran" Naval Academy Press, Constanta, Romania /I The journal is indexed in: PROQUEST / DOAJ / DRJI / JOURNAL INDEX / I2OR / SCIENCE LIBRARY INDEX / Google Scholar / Crossref / Academic Keys / ROAD Open Access / OAJI / Academic Resources / Scientific Indexing Services / SCIPIO

not know the methods of treatment. These answers logically lead to the result in Table 7 .

Table 7. Thrombolytic therapy

\begin{tabular}{|l|l|l|}
\hline $\begin{array}{l}\text { What is } \\
\text { thrombolytic } \\
\text { therapy? }\end{array}$ & $\begin{array}{l}\text { Number of } \\
\text { people } \\
\text { answered }\end{array}$ & $\begin{array}{l}\text { Number of } \\
\text { people } \\
\text { answered } \\
\text { as \% }\end{array}$ \\
\hline $\begin{array}{l}\text { Medicated method } \\
\text { aimed at "melting" } \\
\text { of the formed } \\
\text { thrombus }\end{array}$ & 166 & $51,6 \%$ \\
\hline $\begin{array}{l}\text { Invasive removal of } \\
\text { the thrombus }\end{array}$ & 52 & $16,1 \%$ \\
\hline $\begin{array}{l}\text { Introduction of } \\
\text { drugs stimulating } \\
\text { brain circulation }\end{array}$ & 78 & $24,2 \%$ \\
\hline No comment & 26 & $8,1 \%$ \\
\hline
\end{tabular}

Detected is lack of awareness of the population about the time range for thrombolytic therapy. I Table 8 / Of all people questioned only $51.6 \%$ had pointed out up to $4,5 \mathrm{~h}$.

Table 8. Time range for thrombolytic therapy

\begin{tabular}{|l|l|l|}
\hline $\begin{array}{l}\text { What time } \\
\text { span is } \\
\text { required for } \\
\text { thrombolytic } \\
\text { therapy in } \\
\text { IS? }\end{array}$ & $\begin{array}{l}\text { Number of } \\
\text { people } \\
\text { answered }\end{array}$ & $\begin{array}{l}\text { Number } \\
\text { people } \\
\text { answered as \% }\end{array}$ \\
\hline Up to4,5 h & 180 & $51,6 \%$ \\
\hline Up to 6 h & 94 & $16,1 \%$ \\
\hline Up to12 h & 34 & $24,2 \%$ \\
\hline No comment & 14 & $8,1 \%$ \\
\hline
\end{tabular}

Respondents fall into the following age groups / Table 9 /:

Table 9. Age

\begin{tabular}{|l|l|l|}
\hline $\begin{array}{l}\text { Your age } \\
\text { refers to the } \\
\text { group: }\end{array}$ & $\begin{array}{l}\text { Number of } \\
\text { people } \\
\text { answered }\end{array}$ & $\begin{array}{l}\text { Number } \\
\text { people } \\
\text { answered as \% }\end{array}$ \\
\hline $18-24$ years. & 118 & $36,6 \%$ \\
\hline $25-34$ y. & 24 & $7,5 \%$ \\
\hline $35-44$ y. & 20 & $6,2 \%$ \\
\hline $45-54$ y. & 28 & $8,7 \%$ \\
\hline $55-64$ y. & 60 & $18,6 \%$ \\
\hline $65-74$ y. & 30 & $9,3 \%$ \\
\hline $75-84$ y. & 40 & $12,4 \%$ \\
\hline over 85 years. & 2 & $0,6 \%$ \\
\hline
\end{tabular}

Of special interest is the comparison of the relationship between age and awareness of patients, about use of modern methods for the treatment of IS, which we found through cross table / Table 10/.
Table 10. Knowledge of modern methods by age

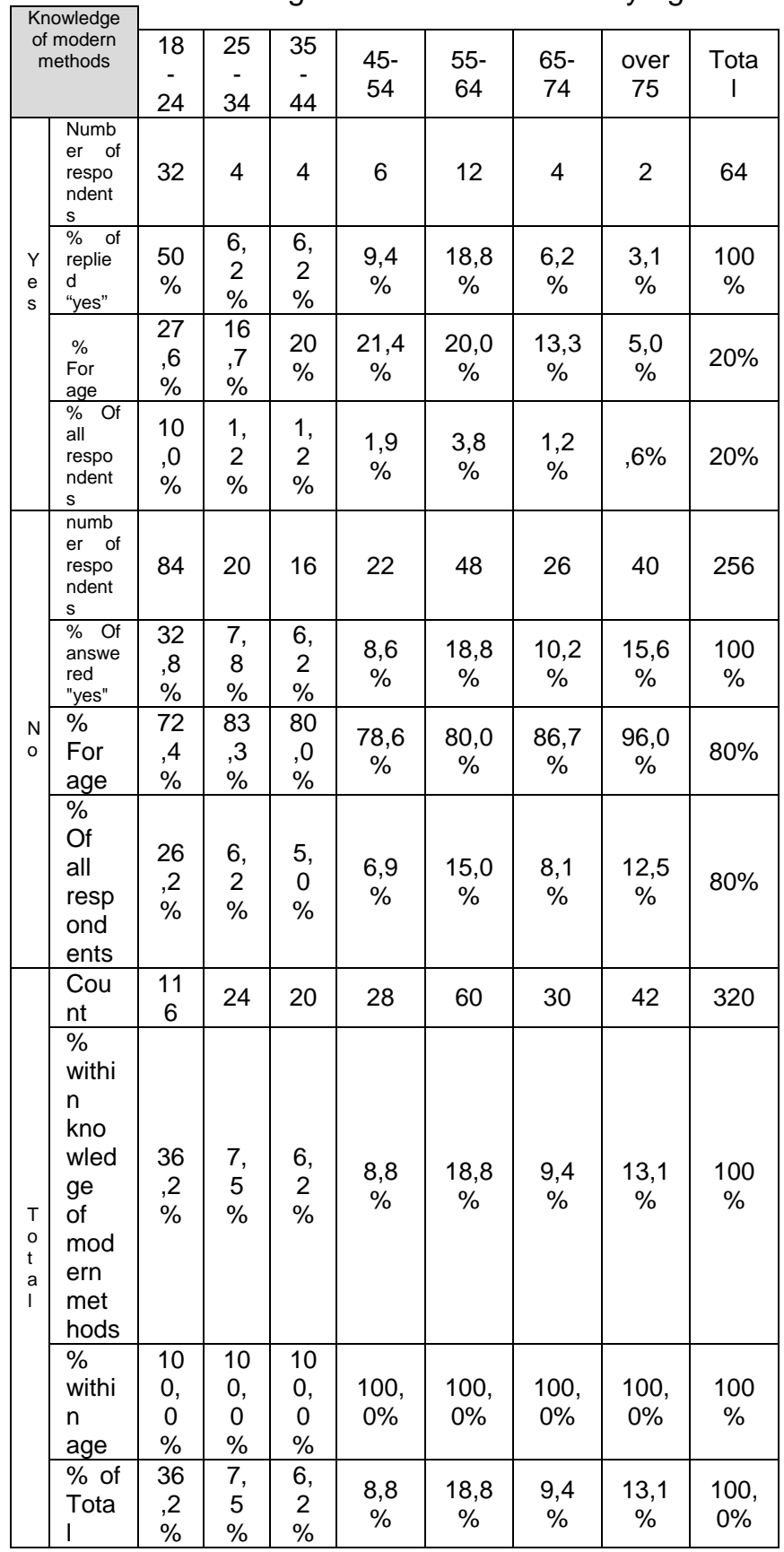

The conclusions that can be drawn from the research team are limited to:

1. The detected low level of awareness of the population leads to a serious risk of delay of treatment the symptoms of IS and inability to implement effective methods of treatment.

2. Due to the inaccuracy in the presentation of the symptoms when calling at tel. 112 , the risk of improper administration of medication increases.

In terms of public awareness is needed to provide accurate and clear specific information. 


\begin{abstract}
"Mircea cel Batran" Naval Academy Scientific Bulletin, Volume XIX - 2016 - Issue 1
Published by "Mircea cel Batran" Naval Academy Press, Constanta, Romania /I The journal is indexed in: PROQUEST / DOAJ / DRJI / JOURNAL INDEX / I2OR / SCIENCE LIBRARY INDEX / Google Scholar / Crossref /

Academic Keys / ROAD Open Access / OAJI / Academic Resources / Scientific Indexing Services / SCIPIO
\end{abstract}

Another important point is the training of the population in the fastest presenting of prominent symptoms when calling at tel: 112 .

Unlike European countries, in Bulgaria the role of the nurse in prevention and disease prevention is not regulated. The important role of health care professionals in providing information for socially significant diseases and training of the population has not been established from this research.

\title{
CONCLUSIONS
}

Thrombolytic therapy is not yet sufficiently developed in Bulgaria. Supporting national and local health institutions is crucial to ensure and provide adequate treatment for stroke. Efforts are needed for adequate funding for health care facilities, training of human resources and public education through the creation of a unified national strategy for its implementation and control, which is to form a state policy in health care with optimal use of public-private partnership.

In some European countries like Germany and Austria, there is a network of specialized centres for treating strokes, with strict organization of how to react in case of an IS - immediate calling on 112, an arrival of an Emergency team, an immediate notification of the hospital and the specialized team that's taking the case, and transporting the patient to the so-called stroke unit. About 3\% of the patients suffering from IS in Europe are being thrombolized. This percentage in our country is much lower. The information is insufficient among the medical community as well, especially among the GP, the outpatient care and first aid teams. Scientific and practical information concerning the problem, can be found mainly in specialized neurological editions which are spread thoroughly among neurologists [2]. Health care professionals involved in primary care could participate actively in prevention, information and training the patients on disease symptoms and regulated activities after signs of stroke. Actively and adequately tracking the patients of the target group will lead to early detection and even prevention of brain incidents. A programme for targeted surveillance of patients with IS who underwent thrombolytic therapy in order to monitor these patients in the long term is needed. It is the introduction of uniform protocols with highly sensitive anchoring points for quick orientation of employees in emergency aid. Good coordination between the emergency team and the multidisciplinary team will help to reduce the loss of time after admitting the patient in a hospital and rapid organization of instrumental and clinical - laboratory and within 60 minutes to start thrombolysis as it is accepted in the European recommendations. In the future, the creation of a large network of specialized clinics for treatment of stroke with thrombolysis is recommended, like the laboratories for the treatment of myocardial infarction because only the treatment in the first hours of the incident would avoid adverse consequences for the patient and society the loss of functional independence and ability to work. The enormous economic burden of high costs for these patients can be [5]. Patients and their families should be able to adequately respond to suspected stroke occurring, indicate the exact time of its occurrence and its exact description. Media must actively participate in the promotion of symptoms and response pattern of the population in case of stroke, similarly to the European and world experience.

\section{BIBLIOGRAPHY}

[1] Andonova V., Miliotov I., Chausheva P., Georgieva R., Molev A. First case in Bulgaria of thrombolysis in the acute fase of IS. In: $9^{\text {th }}$ national congress of neurology with international participation, 8-10 September 2005. Bulgarian Neurology 5, 2005:200 (P122)

[2] Andonova S., Kirov F., Minchev D., Bachvarov Ch., Georgieva V., Bocheva D., Thrombolysis treatment of acute ischemic stroke - pilot research, NEUROSONOGRAPHY AND BRAIN HEMODYNAMICS, vol. 6, 2010, nr. 1, 18p.

[3] Georgieva L, Powles J, Genchev G, Salchev P, Poptodorov G. Bulgarian population in transitional period. Public Health and Peace 43, 2002:240-244.

[4] Staykov I., Thrombolysis therapy for ischemis strokes, nr 92009 , www.medinfo-bg.com

[5] Staykov I., Thrombolysis therapy saves from ischemic stroke in the first 4-5 hours, 2012 http://www.hospital.bg/news-4965-trombolititchna-terapiia-spasiava-pri-insult-v-purvite-4-5-tchasa.html/ [6] Tityanova E., Velcheva I., Stamenov B., Thrombolysis treatment of acute ischemic stroke, NEUROSONOGRAPHY AND BRAIN HEMODYNAMICS, vol 6, 2010, nr 1, 11p.

[7] Todorova E., Thrombolysis is the most effective treatment for ischemic stroke, doctors should not be afraid to apply it, www.zdrave.net, 24.4.2010http://www.zdrave.net/Portal/WeekGuest/Default.aspx?evntid=EG9Zxnmlbz0\%3D

[8] Yankova D., Expansion of the therapeutic window of intravenous thrombolysis in acute ischemic stroke, magazine MD, 2012; http://spisaniemd.bg/md/2012/06/razshiryavane-na-terapevtichniya-prozorets-navenoznata-tromboliza-pri-ostar-ishemichen-insult 


\begin{abstract}
"Mircea cel Batran" Naval Academy Scientific Bulletin, Volume XIX - 2016 - Issue 1
Published by "Mircea cel Batran" Naval Academy Press, Constanta, Romania /I The journal is indexed in: PROQUEST / DOAJ / DRJI / JOURNAL INDEX / I2OR / SCIENCE LIBRARY INDEX / Google Scholar / Crossref / Academic Keys I ROAD Open Access / OAJI / Academic Resources / Scientific Indexing Services / SCIPIO
\end{abstract}

[9] Yankova D., Therapeutic window for Actilyse is up to 4.5 hours from the beginning of the acute ischemic stroke, http://spisaniemd.bg/md/2012/12/terapevtichniyat-prozorets-za-actilyse-do-45-chasa-ot-nachaloto-naostriya-ishemichen-insult

[10] KP №2 Ischemic stroke with thrombolysis, $8^{\text {th }}$ March 2015, 10.18 AM, http://www.nhif.bg/web/guest/40

[11] Medical Standard "Neurological diseases". Ordinance №19/ $2^{\text {nd }}$ August 2006 of Ministry of Healthcare. State Gazette nr.67/18.08.2006

[12] Allender S, Scarborough P, Peto V, Rayner M, Leal J, Luengo-Fernandez R, Gray A. European cardiovascular disease statistics 2008 edition. Department of Public Health, University of Oxford, 2008. European Heart Network

[13] Boehringer Ingelheim gains approval of extended 4.5 hour time-window for Actilyse ${ }^{\circledR}$ in acute ischaemic stroke for majority of EU countrieshttp://www.boehringeringelheim.com/news/news_releases/press_releases/2011/04_november_201 1_altepalse.htlm

[14] Bongers T, de Maat M, van Goor $M$ et al.. High von Willebrand factor levels increase the risk of first ischemic stroke: influence of ADAMTS13, inflammation, and genetic variability. // Stroke 37 (11). 2006. DOI:10.1161/01.STR.0000244767.39962.f7. c. 2672-7

[15] Brain Basics: Preventing Stroke. // National Institute of Neurological Disorders and Stroke. Посетен на 2009-10-24

[16] Donnan GA, M.Fisher, M.Macleod, SM Davis . Stroke. // Lancet 371 (9624). May 2008. DOI:10.1016/S0140-6736(08)60694-7. c. 1612-23.

[17] Ellekjær, H and others. Epidemiology of Stroke in Innherred, Norway, 1994 to 1996 : Incidence and $30-$

Day Case-Fatality Rate. // Stroke 28 (11). November 1, 1997. c. 2180-2184

[18] Guercini F, Acciarresi M, Agnelli G, Paciaroni M. Cryptogenic stroke: time to determine aetiology. /l Journal of Thrombosis and Haemostasis 6 (4). April 2008. DOI:10.1111/j.1538-7836.2008.02903.x. c. 54954

[19] Kidwell CS, Warach S. Acute ischemic cerebrovascular syndrome: diagnostic criteria. // Stroke 34 (12). December 2003. DOI:10.1161/01.STR.0000098902.69855.A9. c. 2995-8

[20] Murray CJ, Lopez AD. Mortality by cause for eight regions of the world: Global Burden of Disease Study. // Lancet 349 (9061). 1997. DOl:10.1016/S0140-6736(96)07493-4. c. 1269-76

[21] Powles J, Kirov P, Feschieva N, Stanoev M, Atanasova V. Stroke in urban and rural populations in northeast Bulgaria: incidence and case fatality findings from a 'hot pursuit' study. BMC Public Health, $2002 ; 2: 24$.

[22] Schellinger P, Hacke W, Fiebach J. Thrombolysis with Alteplase 3 to 4.5 hours after acute stroke. (ECASSIII) N Engl J Med 359, 2008:2839-2841

[23] Senelick Richard C., Rossi, Peter W., Dougherty, Karla. Living with Stroke: A Guide for Families. Contemporary Books, Chicago, 1994.ISBN 0809226073. OCLC 4085688842835161

[24] Shuaib A, Hachinski VC. Mechanisms and management of stroke in the elderly. // CMAJ 145 (5). September 1991. c. 433-43

[25] Stam J. Thrombosis of the cerebral veins and sinuses. // The New England Journal of Medicine 352 (17). April 2005. DOI:10.1056/NEJMra042354. c. 1791-8

[26] The World health report 2004. Annex Table 2: Deaths by cause, sex and mortality stratum in WHO regions, estimates for 2002.. Geneva, World Health Organization, 2004.

[27] Truelsen, T., Piechowski-Jyzwiak, Bonita, R., Mathers, C., Bogousslavski, J., § Boysen, G(2006). Stroke incidence and prevalence in Europe: a review of available data= European Journal of Neurology, 13, 581598

[28] Public health statistics, Bulgaria 2009, Annual. National Center of Health Information. Sofia, 2009

[29] World Health Organisation. Cerebrovascular Disorders (Offset Publications). Geneva, World Health Organisation, 1978. ISBN 9241700432. OCLC 4757533 